\title{
Correction to: Investigations on solitons in $f(\mathcal{R})$-gravity
}

\section{Krishnendu De $\mathrm{e}^{1, \mathrm{a}} \mathbb{C}$, Uday Chand $\mathrm{De}^{2, \mathrm{~b}} \mathbb{C}_{\mathbb{C}}$}

${ }^{1}$ Department of Mathematics, Kabi Sukanta Mahavidyalaya, The University of Burdwan, P.O.-Angus, Hooghly, Bhadreswar, West Bengal 712221, India

2 Department of Mathematics, University of Calcutta, Calcutta, West Bengal, India

(C) The Author(s), under exclusive licence to Società Italiana di Fisica and Springer-Verlag GmbH Germany, part of Springer Nature 2022

\section{Correction to: Eur. Phys. J. Plus (2022) 137:180} https://doi.org/10.1140/epjp/s13360-022-02399-y

In this article, the following references were incorrect and have been changed:

[5] was changed to [1]

[22] was changed to [2]

[8] was changed to [3]

[13] was changed to [4]

[14] was changed to [5]

[15] was changed to [6]

[19] was changed to [7]

[18] was changed to [8]

[10] was changed to [9]

[11]was changed to [10]

[12] was changed to [11]

[6] was changed to [12]

[1] was changed to [13]

[2] was changed to [14]

[4] was changed to [15]

[7] was changed to [16]

[21] was changed to [17]

[3] was changed to [18]

[16] was changed to [19]

[17] was changed to [20]

[9] was changed to [21]

[20] was changed to [22]

The original article can be found online at https://doi.org/10.1140/epjp/s13360-022-02399-y.

a e-mail: krishnendu.de@outlook.in (corresponding author)

be-mail: uc_de@yahoo.com 